\title{
Coordinated changes in photosynthetic machinery performance and water relations of the xerophytic shrub Ziziphus lotus (L.) Lam. (Rhamnaceae) following soil drying
}

\author{
M. MARAGHNI*, M. GORAI ${ }^{*, * *+}$, K. STEPPE ${ }^{* * *}$, M. NEFFATI", and M.C. VAN LABEKE ${ }^{* * * *}$ \\ Laboratoire des Ecosystèmes Pastoraux et Valorisation des Plantes Spontanées et des Micro-organismes Associés, \\ Institut des Régions Arides, Université de Gabès, 4119 Médenine, Tunisia* \\ Unité de Valorisation des Biomolécules Actives, Institut Supérieur de Biologie Appliquée de Médenine, Université \\ de Gabès, 4119 Médenine, Tunisia** \\ Laboratory of Plant Ecology, Faculty of Bioscience Engineering, Ghent University, Coupure links 653, \\ 9000 Ghent, Belgium $^{* * *}$ \\ Department of Plant Production, Faculty of Bioscience Engineering Ghent University, Coupure links 653, \\ 9000 Gent, Belgium $^{* * * *}$
}

\begin{abstract}
Aim of this study was to investigate the effect of water shortage in wild jujube plants, Ziziphus lotus (L.) Lam, and how it is related to its ecological success. All leaf anatomical traits were significantly affected following soil drying. Stressed plants displayed more negative stem water potential $\left(\psi_{\mathrm{w}}\right)$ and osmotic potential values of $c a .-3.5$ and $-4.5 \mathrm{MPa}$, respectively, after $30 \mathrm{~d}$. The relative water content declined although it still maintained high values $(\geq 75 \%)$. The net photosynthetic rate, stomatal conductance, and transpiration rate were significantly inhibited as $\psi_{\mathrm{w}}$ decreased. However, the intrinsic water-use efficiency increased as water deficit was intensified; the difference became significant only after $30 \mathrm{~d}$. As a consequence, the effective quantum yield of PSII photochemistry and the photochemical quenching coefficient significantly decreased although the maximal quantum yield of PSII photochemistry ratio remained statisticaly unchanged. Plants could maintain their water status sufficiently by increasing proline 1.7-fold and sucrose 1.8-fold in their leaves, respectively. The largest accumulation of both solutes may avoid photodamages at cellular level and play a critical role in maintaining osmotic adjustment.
\end{abstract}

Additional key words: chlorophyll fluorescence; drought; gas exchange; osmotic adjustment; water relations..

\section{Introduction}

Drought is the most complex and devastating abiotic stress on a global scale and its frequency is expected to increase as a consequence of climate changes (Ceccarelli 2010). Water availability is an important factor affecting photosynthesis, growth, and survival of plants, mainly in arid and semiarid regions, such as the Mediterranean basin. In recent years, many studies have focused on characterizing the adaptive strategies of plants to water stress (Kreuzwieser and Rennenberg 2014, Gorai et al. 2015). Plants express various responses to drought stress and develop a wide range of physiological and morphological strategies that allow them to cope with drought stress (Torrecillas et al. 1999, Augé et al. 2003). Chlorophyll (Chl) fluorescence constitutes an important selection criterion to verify plant tolerance to abiotic stresses (Maxwell and Johnson 2000, Baker and Rosenquist 2004, Song et al. 2009, Zhang et al. 2010). Under water stress conditions, regulation of sunlight is necessary to balance the absorption and utilization of light energy, thereby minimizing the potential for photooxidative damage (Müller et al. 2001). The photoprotective mechanism competes with photochemistry for the absorbed energy, which in turn leads to decreasing quantum yield of PSII (Genty et al. 1989). Moreover, water shortage decreases the rate of plant $\mathrm{CO}_{2}$ assimilation as a consequence of the reduced stomatal conductance $\left(g_{\mathrm{s}}\right)$ and/or by direct damage to carbon metabolism (Aroca et al. 2012, Nikinmaa et al. 2013). A metabolic response to drought stress is the synthesis of compatible organic solutes, such as soluble sugars, sugar alcohols, proline, and betaines (Serraj and Sinclair 2002, Gorai et al. 2015).

$\overline{\text { Received }} 27$ November 2017, accepted 20 July 2018.

${ }^{+}$Corresponding author; phone: (+216)75633919, fax: (+216)75633918, e-mail: gorai.mustapha@yahoo.fr

Abbreviations: $\mathrm{Chl}$ - chlorophyll; $\mathrm{DM}$ - dry mass; $E$ - transpiration rate; $\mathrm{F}_{0}$ - minimum fluorescence; $\mathrm{F}_{\mathrm{m}}-$ maximum fluorescence; $\mathrm{F}_{\mathrm{v}} / \mathrm{F}_{\mathrm{m}}-$ maximum quantum efficiency of PSII $\left(\mathrm{F}_{\mathrm{v}}=\mathrm{F}_{\mathrm{m}}-\mathrm{F}_{0}\right) ; \mathrm{FM}-$ fresh mass; $g_{\mathrm{s}}-$ stomatal conductance; $P_{\mathrm{N}}-$ net photosynthetic rate; $\mathrm{q}_{\mathrm{N}}$ - nonphotochemical quenching coefficient; $\mathrm{q}_{\mathrm{P}}$ - photochemical quenching coefficient; RWC - relative water content; WUE - intrinsic water-use efficiency $\left(=P_{\mathrm{N}} / g_{\mathrm{s}}\right) ; \Phi_{\mathrm{PSII}}-$ effective quantum yield of PSII photochemistry; $\psi_{\mathrm{w}}-$ water potential; $\psi_{\pi}-$ osmotic potential. 
These solutes reduce the oxidative damage caused by free radicals, especially in response to severe drought stress (Attipali et al. 2004).

Mediterranean shrubs represent excellent models for studying plant responses to drought, which are generally tolerant and well adapted to decreased soil water availability during the seasonal drought. Ziziphus species developed a series of adaptation mechanisms allowing them to tolerate severe conditions. They prevent transpiration and oxidative damage in tissues by strong stomatal control (Choudhary et al. 1996, Clifford et al. 1998, Arndt et al. 2001, Maraghni et al. 2014). Ziziphus lotus is endemic to the Mediterranean basin, while in Tunisia it has a wide ecological and geographical distribution and grows under a variety of environmental conditions. Wild jujube is dormant from October through March and mature plants flower in May, their fruits ripen in August, and their leaves begin to fall in early September (Gorai et al. 2010). In arid ecosystems, this multipurpose shrub contributes to biodiversity conservation. Wild jujube has as great economic and ecological interest: it stabilizes sand dunes and has feed, fuel, and medicinal uses (Le Floc'h 1983, Gorai et al. 2010, Maraghni et al. 2010). The jujube fruits are formed of red exocarp, edible fleshy mesocarp and stony endocarp with 1-2 seeds (Maraghni et al. 2010). The drupe can be consumed fresh, dried or processed (jams, loaf, cakes, jelly, etc.).

The aim of this study was to investigate the photosynthetic performance in drought-treated Ziziphus lotus plants, both in terms of $\mathrm{CO}_{2}$ assimilation, as measured by leaf gas exchange, and of the functionality of the photosynthetic apparatus, as assessed by $\mathrm{Chl} a$ fluorescence measurements. Additionally, coordinated changes between photosynthesis and water relations were designed to increase understanding of preliminary alterations of physiological characteristics for this species.

\section{Material and methods}

Plant material, growth conditions, and experimental design: The experiments were carried out in a glasshouse at the Faculty of Bioscience Engineering, Ghent University, Belgium $\left(51^{\circ} 02^{\prime} \mathrm{N}, 03^{\circ} 42^{\prime} \mathrm{E}\right)$. Seeds were provided by the seed bank of the Laboratoire des écosystèmes pastoraux et valorisation des plantes spontanées et des microorganismes associés at the Institut des Régions Arides, Médenine, Tunisia.

After surface sterilization, seeds were sown in alveolar plates filled with loam and placed at controlled conditions (Maraghni et al. 2010). After two weeks the seedlings were selected according to their uniformity and transplanted in plastic bags (14 $\mathrm{cm}$ in diameter and $60 \mathrm{~cm}$ in depth) attached by metal brackets and filled with a mixture of soil (loam soil) and sand $(2: 1 ; \mathrm{v} / \mathrm{v})$. They were watered (drip irrigation) with water-soluble fertilizer of 10-10-10 $\left(\mathrm{N}-\mathrm{P}_{2} \mathrm{O}_{5}-\mathrm{K}_{2} \mathrm{O}\right)$ (Scotts-Sierra Horticultural Products Co., Marysville, OH, USA). The pots were placed in a glasshouse with natural sunlight and the mean average day and night time temperatures were 30 and $18^{\circ} \mathrm{C}$, respectively. After eight months of culture, the seedlings were subjected to two irrigation treatments; (1) irrigation to field capacity (control) and (2) withholding water during 14 and $30 \mathrm{~d}$. They were randomly allocated to four blocks and each block consisted of 12 plants (4 plants for each treatment) giving a total of 16 plants per treatement. At the beginning of the experiment, all bags were saturated with water and allowed to drain freely by the drainage holes.

Plant water relations: The water status was evaluated by measuring relative water content (RWC) on fully expanded leaves according to Morgan (1984): RWC $=[(\mathrm{FM}-\mathrm{DM}) /$ $(\mathrm{TM}-\mathrm{DM}) \times 100]$, where FM, DM, and TM are the fresh, dry, and turgid masses, respectively. Stem water potential $\left(\psi_{\mathrm{w}}\right)$ was measured using a Scholander pressure chamber (PMS Instruments Co., Corvallis, R, USA) and osmotic potential $\left(\psi_{\pi}\right)$ was determined according to Callister et al. (2006). About $20 \mathrm{mg}$ of leaf DM were extracted in $1 \mathrm{ml}$ of distilled water. The homogenate was placed in a water bath at $100^{\circ} \mathrm{C}$ for $1 \mathrm{~h}$ and centrifuged at $10,000 \times \mathrm{g}$ for $10 \mathrm{~min}$ at $4^{\circ} \mathrm{C}$. A $100-\mu$ laliquot of the extract was used to determine osmolarity with a micro-osmometer (Fiske ${ }^{\circledR}$ Model 210, Fiske ${ }^{\circledR}$ Associates).

Photosynthetic gas exchange and $\mathrm{Chl}$ fluorescence: The net photosynthetic rate $\left(P_{\mathrm{N}}\right)$, stomatal conductance $\left(g_{\mathrm{s}}\right)$, and transpiration rate $(E)$ of fully expanded leaves were determined between 9:00 $\mathrm{h}$ and noon using a LI-COR 6400 portable photosynthesis system (LI-COR, Lincoln, NE, $\mathrm{US} A$ ). Leaf temperature was kept constant at $25^{\circ} \mathrm{C}$, relative air humidity in the cuvette at $60 \%$, the $\mathrm{CO}_{2}$ concentration in the chamber was $400 \mu \mathrm{mol} \mathrm{mol}^{-1}$, and a light intensity of $1,500 \mu \mathrm{mol}$ (photon) $\mathrm{m}^{-2} \mathrm{~s}^{-1}$. Intrinsic water-use efficiency $\left(\mathrm{WUE}_{\mathrm{i}}\right)$ was calculated from the ratio $P_{\mathrm{N}} / g_{\mathrm{s}}$.

Chl $a$ fluorescence in dark- and light-adapted leaves was measured with a portable fluorometer (PAM-2500, Walz, Effeltrich, Germany). After 30 min of dark adaptation, the maximal quantum yield of PSII photochemistry $\left(\mathrm{F}_{\mathrm{v}} / \mathrm{F}_{\mathrm{m}}\right)$ was calculated as $\left[\left(\mathrm{F}_{\mathrm{m}}-\mathrm{F}_{0}\right) / \mathrm{F}_{\mathrm{m}}\right]$, where $\mathrm{F}_{\mathrm{m}}$ [induced by a short pulse $(0.6 \mathrm{~s})$ of saturating light of $3,450 \mu \mathrm{mol}$ (photon) $\mathrm{m}^{-2} \mathrm{~s}^{-1}$ ] and $\mathrm{F}_{0}$ were the maximal and minimal fluorescence (Genty et al. 1989). After 4 min of illumination with continuous red, nonsaturating actinic light $\left[447 \mu \mathrm{mol}\left(\right.\right.$ photon) $\mathrm{m}^{-2} \mathrm{~s}^{-1}$ ] and saturating pulses every $25 \mathrm{~s}$, maximum $\left(\mathrm{F}_{\mathrm{m}}{ }^{\prime}\right)$ and steady-state $\left(\mathrm{F}_{\mathrm{s}}\right)$ fluorescence signals were measured in light-adapted leaves. Then, the actinic light was turned off and a far-red pulse was applied to obtain the minimal fluorescence after the PSI excitation $\left(\mathrm{F}_{0}{ }^{\prime}\right)$. The effective quantum yield of PSII photochemistry $\left(\Phi_{\text {PSII }}\right)$ was calculated as $\left[\left(\mathrm{F}_{\mathrm{m}},-\mathrm{F}_{\mathrm{s}}\right) /\right.$ $\left.\mathrm{F}_{\mathrm{m}}{ }^{\prime}\right]$ and $\mathrm{q}_{\mathrm{p}}$ was calculated as $\left[\left(\mathrm{F}_{\mathrm{m}}{ }^{\prime}-\mathrm{F}_{\mathrm{s}}\right) /\left(\mathrm{F}_{\mathrm{m}}{ }^{\prime}-\mathrm{F}_{0}{ }^{\prime}\right)\right]$ (Van Kooten and Snel 1990). Values were obtained for four leaves (one leaf per plant) and per treatment.

Leaf anatomical measurements: Newly formed leaves on the sun-exposed side of seedlings were selected for anatomical observations. In the laboratory, the selected leaves were disinfected in 5\% sodium hypochlorite followed by three rinses with distilled water. The sections were taken from the middle of the leaves to avoid differential thickness along the leaf. Samples were 
fixed in mixture of (FAA) formalin: acetic acid: alcohol (ethanol). The fixed samples were dehydrated through an alcohol series $(50,60,70,85$, and $100 \%)$ and embedded in paraffin during $24 \mathrm{~h}$ at $40^{\circ} \mathrm{C}$. The sections were cut using a microtome and they were then stained with aqueous safranin and Fast Green to distinguish the different cells. After successive steps in the alcohol series and xylene (5-10 min, per solution) each section was mounted on Canada balsam. Finally, three sections per leaf were selected and used to determine the thickness $(\mu \mathrm{m})$ of the palisade and spongy mesophyll and the upper and lower epidermis using an Olympus IX81 inverted fluorescence microscope equipped with an X-Cite Series $120 Q \mathrm{UV}$ lamp and an Olympus XM10 camera, which was connected to a Nikon Alr laser scanning microscope equipped with Axiovision software (LiMiD).

Determination of organic solutes: Free proline content was quantified as described by Bates et al. (1973). Leaf samples $(0.5 \mathrm{~g})$ were homogenized in $3 \%(\mathrm{w} / \mathrm{v})$ sulphosalicylic acid and homogenate was filtered through filter paper. After addition of acid ninhydrin and glacial acetic acid, resulting mixture was heated at $100^{\circ} \mathrm{C}$ for $1 \mathrm{~h}$ in water bath. Reaction was then stopped in ice. The mixture was extracted with toluene, and the absorbance was read at 520 nm (Nanoquant Infinite M200, TECAN Austria GmbH, Austria). Proline concentration was determined using a calibration curve and expressed as $\mu \mathrm{mol}$ (proline) $\mathrm{g}^{-1}(\mathrm{FM})$.

Sugars from leaves were extracted with $80 \%$ ethanol at $70^{\circ} \mathrm{C}$, and centrifuged at $5,000 \times g$ for $10 \mathrm{~min}$. Glucose, fructose, and sucrose were analysed using high-pH anionexchange chromatography with pulsed amperometric detection (Waters; CarboPac MA1 column with companion guard column, eluent: $50 \mathrm{mM} \mathrm{NaOH}, 22^{\circ} \mathrm{C}$ ).

Statistical analysis: Means were compared using the least significant difference (LSD) test $(p \leq 0.05)$. Statistical analyses were performed using SPSS v.17.0.

\section{Results}

Leaf anatomical traits: All leaf anatomical traits were significantly affected following soil drying (Table 1). Epidermis from both sides of $Z$. lotus leaves was thicker in stressed plants compared to well-irrigated plants as water deficit intensified. The epidermis thickness was more pronounced for the upper side compared to the lower one. Leaf mesophyll had different thickness layers and palisade mesophyll was thicker than spongy mesophyll in well- watered plants. As water deficit intensified, the palisade mesophyll thickness decreased reaching similar thickness of spongy mesophyll after $30 \mathrm{~d}$. Both mesophyll tissues evolve in an inverse trend as a response to water shortage, where the thickness declined by $22 \%$ for palisade tissue, and increased by $7 \%$ for spongy tissue after withholding water for $30 \mathrm{~d}$.

Stem water relations: $\psi_{\mathrm{w}}$ was related to relative water content (RWC), indicating that its decrease during the drought stress period was associated with a decrease in RWC (Fig. 1A). Withholding watering throughout the experimental period significantly affected RWC $\left(F_{2,6}=\right.$ $10.63, P<0.05)$, which was decreased by 3.8 and $9.5 \%$ compared with control plants after $14-\mathrm{d}$ and $30-\mathrm{d}$ of the drought stress treatment, respectively. Stem $\psi_{\mathrm{w}}$ and $\psi_{\pi}$ decreased significantly with on-going drought stress $\left(F_{2,6}=75.55\right.$ and 19.74 , respectively; $\left.P<0.05\right)$. The largest reduction in $\psi_{\mathrm{w}}$ occurred in drought-stressed stems on day 30 , when it dropped to $-3.5 \mathrm{MPa}$. A similar pattern was observed in $\psi_{\pi}$ but there was an additional decline to $-4.2 \mathrm{MPa}$. There was a significant positive correlation between $\psi_{\mathrm{w}}$ and $\psi_{\pi}(r=0.88 ; P<0.01)$. Stem turgor values were derived from plots of $\psi_{\mathrm{w}}$ and $\psi_{\pi}$ recorded during the experiment (Fig. 1B). The proximity of points to the zero line showed that variations in turgor potential $\left(\psi_{\mathrm{p}}\right)$ were the smallest for well-irrigated plants and largest for droughtstressed plants after 14 and $30 \mathrm{~d}$, respectively, which is explained by accumulation of organic solutes to cope with water shortage.

Gas exchange and $\mathrm{Chl} \boldsymbol{a}$ fluorescence: Drought stress induced a significant decline in net photosynthetic rate $\left(P_{\mathrm{N}}\right)$, stomatal conductance $\left(g_{\mathrm{s}}\right)$, and transpiration rate (E) $\left(F_{2,6}=35.36,48.42\right.$, and 13.00 , respectively; $P<0.01$; Fig. $2 A-C)$. The values of $P_{\mathrm{N}}$ of well-watered plants reached $13.5 \mu \mathrm{mol}\left(\mathrm{CO}_{2}\right) \mathrm{m}^{-2} \mathrm{~s}^{-1}$; however, withholding water decreased $P_{\mathrm{N}}$ of stressed plants which became significant after $14 \mathrm{~d}$ reaching a value of around $8.5 \mu \mathrm{mol}\left(\mathrm{CO}_{2}\right) \mathrm{m}^{-2} \mathrm{~s}^{-1}$ (Fig. 2A). There was additional decline in $P_{\mathrm{N}}$ after $30 \mathrm{~d}$ which was inhibited by $59 \%$ compared with control plants. In parallel, $E$ reached the highest value $\left[8.5 \mathrm{mmol}\left(\mathrm{H}_{2} \mathrm{O}\right) \mathrm{m}^{-2} \mathrm{~s}^{-1}\right]$ in control plants, and was inhibited by $31 \%$ after withholding water for $14 \mathrm{~d}$, and by $59 \%$ after $30 \mathrm{~d}$ (Fig. $2 B$ ). As compared to controls, $g_{\mathrm{s}}$ of drought-treated plants decreased by 44 and $66 \%$ after $14 \mathrm{~d}$ and $30 \mathrm{~d}$ of withholding water, respectively (Fig. 2C). The $P_{\mathrm{N}} / g_{\mathrm{s}}$ ratio which is an index of leaf intrinsic water-use efficiency $\left(\mathrm{WUE}_{\mathrm{i}}\right)$ increased by prolonging water deficit.

Table 1. Leaf anatomical traits in drought-treated Ziziphus lotus. Means \pm SE $(n=4)$.

\begin{tabular}{lllll}
\hline Parameter size $[\mu \mathrm{m}]$ & Control & $\begin{array}{l}\text { Drought } \\
\text { 14-d }\end{array}$ & 30-d & $p$-value \\
\hline Upper epidermis & $23.88 \pm 1.10$ & $27.54 \pm 0.30$ & $27.86 \pm 0.03$ & 0.010 \\
Lower epidermis & $16.30 \pm 0.48$ & $19.68 \pm 0.20$ & $19.16 \pm 1.04$ & 0.025 \\
Palisade mesophyll & $58.36 \pm 1.56$ & $57.45 \pm 0.00$ & $45.57 \pm 0.00$ & 0.000 \\
Spongy mesophyll & $42.80 \pm 0.86$ & $43.44 \pm 0.00$ & $45.67 \pm 0.01$ & 0.016 \\
\hline
\end{tabular}



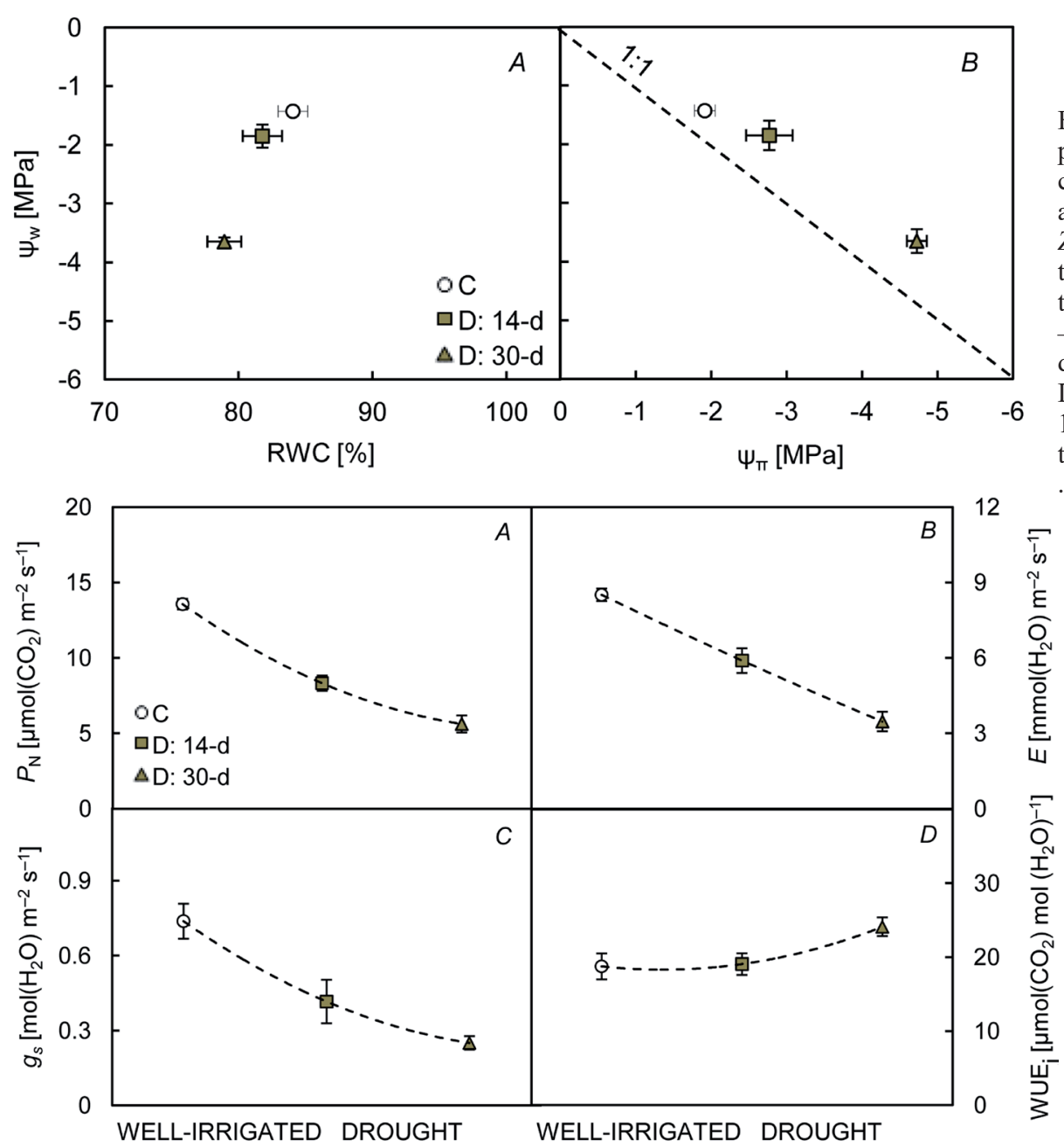

Fig. 1. Relationship between water potential $\left(\psi_{\mathrm{w}}\right)$ and relative water content (RWC) $(A)$ and between $\psi_{\mathrm{w}}$ and $\psi_{\pi}$ (osmotic potential) (B) for Ziziphus lotus in control and droughttreated plants by withholding watering throughout the experimental period. C - control plants (O), D - 14- and 30-d drought period ( and $\boldsymbol{\Delta}$, respectively). Data represent mean \pm SE, $n=4$. The $1: 1$ line indicates $\psi_{\mathrm{w}}=\psi_{\pi}$ and hence turgor potential $=0$.

Fig. 2. Changes in $(A)$ potosynthetic assimilation rate $\left(P_{\mathrm{N}}\right),(B)$ transpiration rate $(E),(C)$ stomatal conductance $\left(g_{\mathrm{s}}\right)$, and $(D)$ intrinsic water-use efficiency (WUE $)_{\mathrm{i}}$ ) of Ziziphus lotus in control and drought- treated plants by withholding watering throughout the experimental period. Lines describing the dependencies were obtained using a polynomial regression. C - control plants ( $($ ), D - 14- and 30-d drought period ( $\boldsymbol{\square}$ and $\boldsymbol{\Lambda}$, respectively). Values represent means \pm SE, $n=4$.

Stressed plants displayed higher $\mathrm{WUE}_{\mathrm{i}}$ values than that in control plants only after $30 \mathrm{~d}$, where the differences become significant (Fig. 2D).

Water-deficit stress significantly affected the effective quantum yield of PSII photochemistry $\left(\Phi_{\mathrm{PSII}}\right)$ and photochemical quenching coefficient $\left(\mathrm{q}_{\mathrm{P}}\right)\left(F_{2,6}=80.20\right.$ and 17.61, respectively; $P<0.01$ ) (Fig. $3 B, D$ ). Well-watered plants displayed higher $\Phi_{\text {PSII }}$ than stressed plants, which was markedely declined by $17 \%$ after withholding water for $14 \mathrm{~d}$, and to $53 \%$ after $30 \mathrm{~d}$. Similarly, $\mathrm{q}_{\mathrm{P}}$ decreased gradually with on-going drought stress and the largest reduction in $\mathrm{q}_{\mathrm{P}}$ occurred in stressed leaves on day 30, when it dropped by $60 \%$ compared with control ones. In contrast, maximal quantum yield of PSII photochemistry $\left(\mathrm{F}_{\mathrm{v}} / \mathrm{F}_{\mathrm{m}}\right)$ and nonphotochemical quenching coefficient $\left(\mathrm{q}_{\mathrm{N}}\right)$ did not differ significantly (Fig. $3 A, C$ ). The values of $\mathrm{F}_{\mathrm{v}} / \mathrm{F}_{\mathrm{m}}$ ranged predominantly between 0.75 and 0.77 . The $\mathrm{q}_{\mathrm{N}}$ had no consistent pattern of increase or decrease reaching a value of 0.6 .

Accumulation of organic solutes: Sucrose significantly accumulated in leaves as water deficit stress intensified representing $c a .121$ and $183 \%$ of the control value after withholding water for $14 \mathrm{~d}$ and $30 \mathrm{~d}$, respectively $\left(F_{2,6}=\right.$ 16.28, $P<0.01$; Fig. $4 A$ ). Similarly, accumulation of proline was significantly induced by $12 \%$ after withholding water for $14 \mathrm{~d}$, and to $73 \%$ after $30 \mathrm{~d}\left(F_{2,6}=59.7, P<0.001\right.$; Fig. $2 B$ ). In contrast, glucose and fructose did not change significantly by prolonging drought stress (Fig. 4A).

\section{Discussion}

Results from this study indicate that drought-stressed plants displayed less negative $\psi_{\mathrm{w}}$ as water deficit intensified and allowed their leaves to carry out photosynthesis. The additional decrease in $\psi_{\pi}$ resulted in accumulation of compatible solutes such as sucrose and proline, indicating their contribution to osmotic adjustment. Futhermore, plants shifted their leaf anatomical behaviour by moving from mesic (well-watered) to xeric conditions (droughtstressed). They exhibited a significant increase in the thickness of epidermis and spongy parenchyma under 


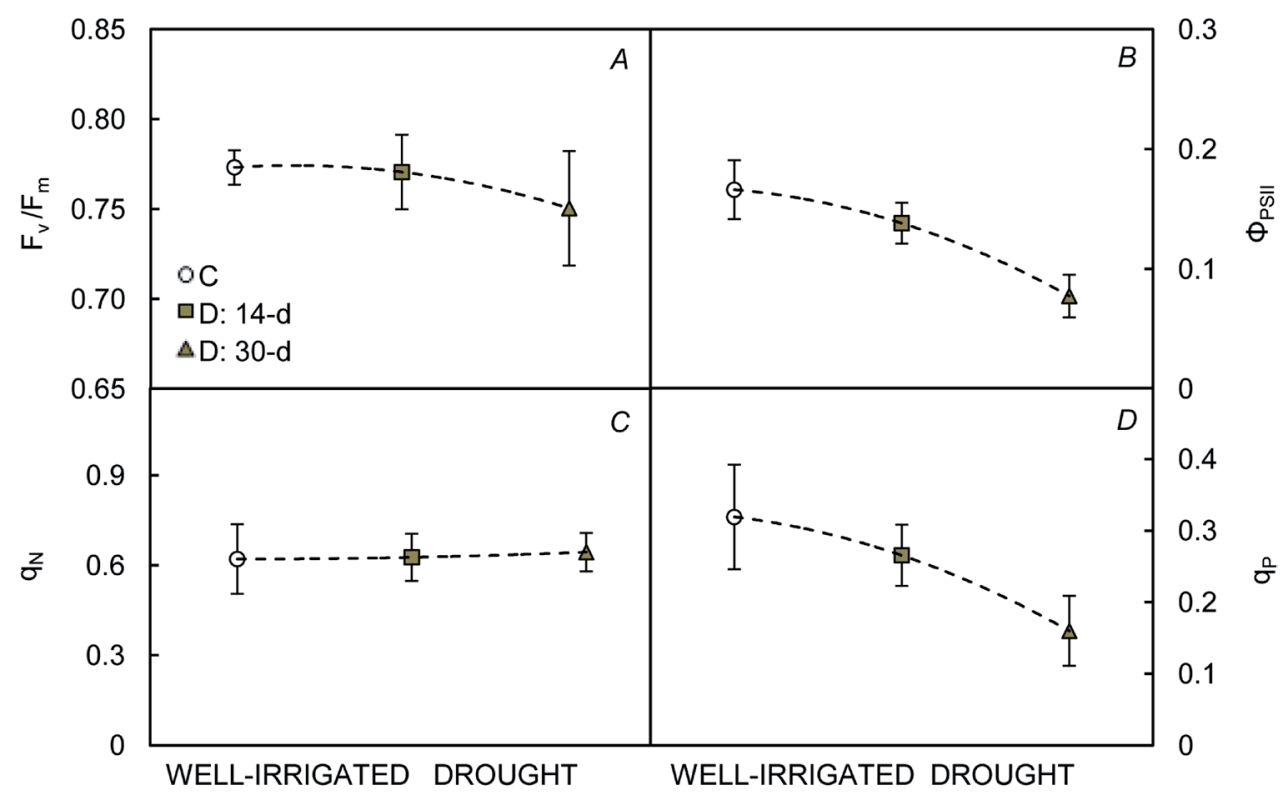

Fig. 3. Changes in $(A)$ maximal quantum yield of PSII photochemistry $\left(\mathrm{F}_{\mathrm{v}} / \mathrm{F}_{\mathrm{m}}\right),(B)$ effective quantum yield of PSII photochemistry $\left(\Phi_{\mathrm{PSII}}\right),(C)$ nonphotochemical quenching coefficient $\left(\mathrm{q}_{\mathrm{N}}\right)$, and $(D)$ photochemical quenching coefficient $\left(\mathrm{q}_{\mathrm{P}}\right)$ of Ziziphus lotus in control and drought-treated plants by withholding watering throughout the experimental period. Lines describing the dependencies were obtained using a polynomial regression. C - control plants (O), D - 14- and 30-d drought period ( $\square$ and $\boldsymbol{\Lambda}$, respectively). Values represent means $\pm \mathrm{SE}, n=4$.

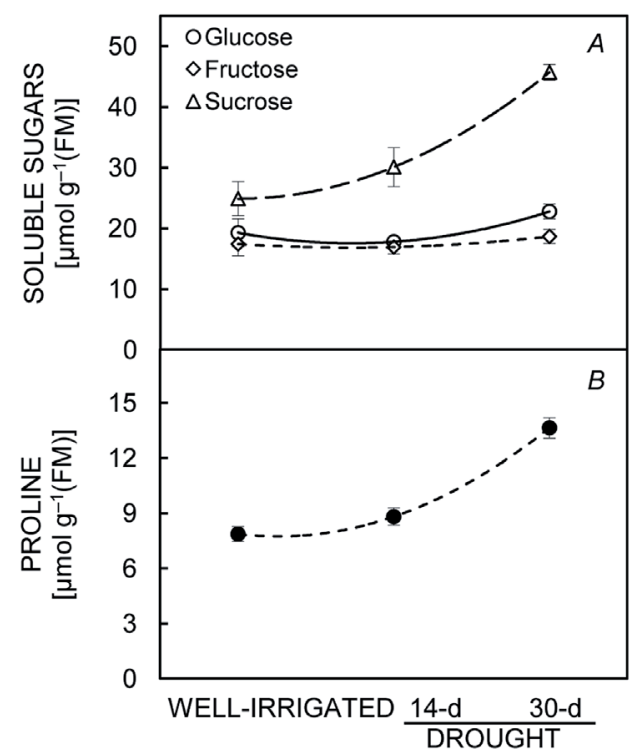

Fig. 4. Contents of $(A)$ soluble sugars (glucose, fructose, and sucrose) and (B) proline in leaves of Ziziphus lotus in control and drought-treated plants by withholding watering throughout the experimental period. Lines describing the dependencies were obtained using a polynomial regression. Values represent means $\pm \mathrm{SE}, n=4$.

water deficit stress, whereas palisade parenchyma was slightly reduced. The increase in the number of epidermal cells per leaf surface unit reflects a better control of water loss through cuticular transpiration (Bosabalidis and Kofidis 2002). This leaf anatomical behavior may enhance survival and growth under deficit water by improving water relations and providing higher protection for the internal cells (Bacelar et al. 2004). $\psi_{\mathrm{w}}$ and $\psi_{\pi}$ were linearly related to RWC, which declined although it still maintained high values. This supports findings on other species of the same genus including Z. mauritiana (Clifford et al. 1998), Z. rotundifolia (Arndt et al. 2001), and Z. mauritiana (Kulkarni et al. 2010). It was shown (Lawlor and Cornic 2002) that photosynthetic rate of leaves in higher plants is known to decrease as the RWC and leaf $\psi_{\mathrm{w}}$ decrease. Maintaining leaf RWC under lowering $\psi_{\mathrm{w}}$ is an important adaptation exhibited by $Z$. lotus to cope with extreme drought conditions. Similarly, Kala et al. (2008) reported higher tolerance ability of Z. nummularia after $28 \mathrm{~d}$ of drought stress, which is associated with maintenance of better leaf RWC as compared to Z. rotundifolia. The relationship between RWC and $\psi_{\mathrm{w}}$ has often been used to quantify the dehydration tolerance: tissues, which maintain a high RWC as $\psi_{\mathrm{w}}$ decreases are more tolerant to dehydration. In the present study, leaves of $Z$. lotus decreased their RWC values from 84 to $79 \%$ and did not drop below $60 \%$, which is a typical characteristic of drought-tolerant species (Kawaguchi et al. 2004, Gorantla et al. 2007, Perera et al. 2008, Gorai et al. 2015).

Lowering leaf gas exchange $\left(\mathrm{H}_{2} \mathrm{O}\right.$ and $\left.\mathrm{CO}_{2}\right)$ is a main physiological response for $Z$. lotus to adapt to water deficit stress. Similar results have also been documented for some Ziziphus species such as Z. mauritiana (Clifford et al. 1998, Kulkarni et al. 2010) and Z. rotundifolia (Arndt et al. 2001). The inhibition of carbon assimilation in $Z$. lotus leaves by withholding watering is associated with a decline in stomatal conductance by involving stomatal closure. This pattern in leaf gas exchange is due to the cessation of plant growth associated with reduced availability of photoassimilates to apical sink region.

Xerophytic plants reduce stomatal conductance as soil water potential decreases and vapour pressure deficit of 


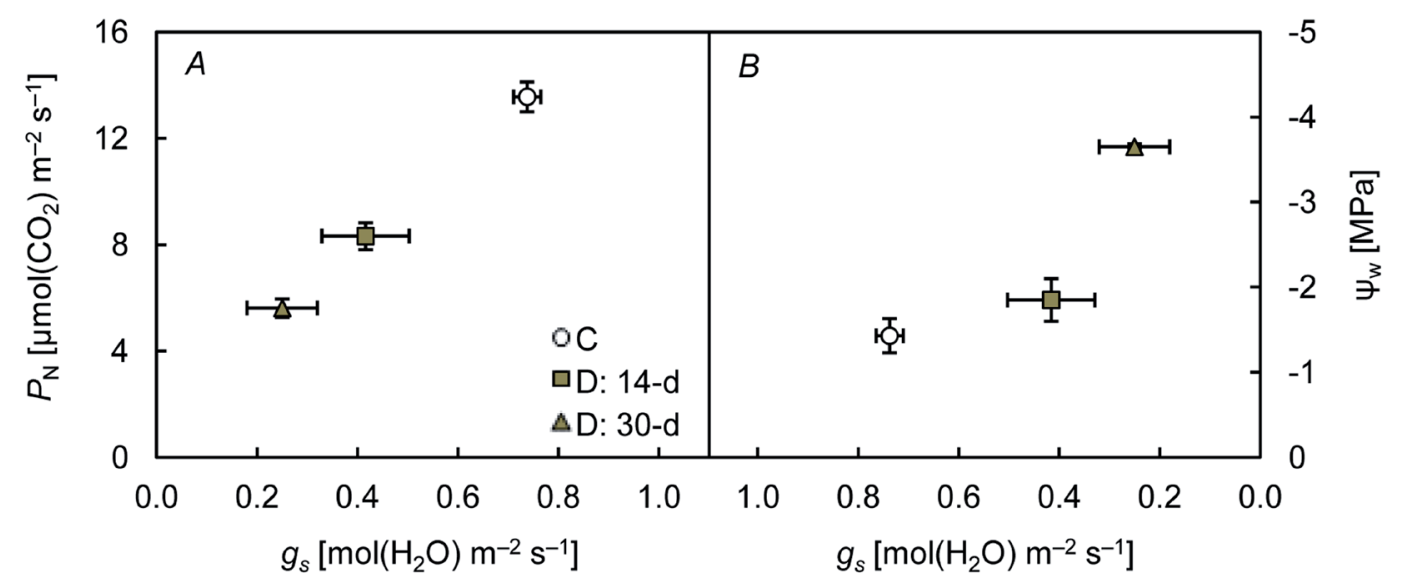

Fig. 5. Relationship between $P_{\mathrm{N}}$ and $g_{\mathrm{s}}(A)$, and between $\psi_{\mathrm{w}}$ and $g_{\mathrm{s}}(B)$ for Ziziphus lotus in control and drought-treated plants by withholding watering throughout the experimental period. C - control plants ( $\odot), \mathrm{D}-14$ - and 30 -d drought period ( $\bullet$ and $\boldsymbol{\Delta}$, respectively). Values represent means $\pm \mathrm{SE}, n=4$.

the air drops, thereby maintaining a relatively constant $\psi_{\mathrm{w}}$ (Chapotin et al. 2006). The relationship of stomatal conductance with $\psi_{\mathrm{w}}$ depends on the genotype (Tardieu and Simmonneau 1998), the environmental conditions during osmotic stress (Sharkey 1990), and the intensity of osmotic stress (Flexas et al. 1999). Z. lotus displayed sensitive stomatal responses, which result from lowering stem $\psi_{\mathrm{w}}$ $(r=0.88, P<0.01)$ (Fig. 5B). The decrease in $E$ along with the lower stem $\psi_{\mathrm{w}}$ and $\psi_{\pi}$ suggesting that $g_{\mathrm{s}}$ was effective in regulating the water balance of this species during drought stress. The relationship between $P_{\mathrm{N}}$ and $g_{\mathrm{s}}$ have received increasing recent attention due to the trade-off between water loss and carbon gain experienced by plants during extreme, climate change-type drought (McDowell et al. 2008). Our data show that both parameters are involved in decreasing gradually with on-going drought stress in a manner that improves water-use efficiency (Fig. 5A), indicating an optimisation of carbon uptake $v s$. water loss (Raven 2002). This positive correlation $(r=0.84, P<0.01)$ revealed that $g_{\mathrm{s}}$ plays a strong control over photosynthetic assimilation and the diffusional limitations restricting the supply of $\mathrm{CO}_{2}$ to metabolism of $Z$. lotus plants. Moreover, photochemical processes are affected not only by photoinhibition and photo-oxidation but stomatal factors are also involved. According to Chaves (1991), this close relationship between $P_{\mathrm{N}}$ and $g_{\mathrm{s}}$ is also a common feature of drought-adapted species. The present data is in agreement with various studies (Arndt et al. 2001, Rouhi et al. 2007, De Smedt et al. 2012). The maintaining of higher leaf RWC of Z. lotus plants during water deficit stress was probably the result of their better water-use efficiency through controlled $E$ under drought stress to avoid excess water loss.

Chl fluorescence data show that $\mathrm{F}_{\mathrm{v}} / \mathrm{F}_{\mathrm{m}}$ did not change significantly with prolonging drought, indicating that photosynthetic efficiency was stable and was not affected when $P_{\mathrm{N}}$ declined. This behavior confirms that $\mathrm{F}_{\mathrm{v}} / \mathrm{F}_{\mathrm{m}}$ ratio change only when drought stress becomes more severe and it is not a sensitive indicator of drought stress. Results from this study demonstrate that withholding watering significantly decreased $\Phi_{\mathrm{PSII}}$ and $\mathrm{q}_{\mathrm{P}}$. The same finding has been reported on Olea europaea (Boussadia et al. 2008) and Vigna unguiculata (Souza et al. 2004). Changes in $\mathrm{q}_{\mathrm{N}}$ in response to drought were relatively small, thus allowing maintenance of electron transport through photosystems at considerable rates. The decrease in photosynthetic capacity during drought stress was accompanied by reduction in $\Phi_{\text {PSII. }}$. This decline could be considered as a downregulation of PSII that reflect the protective or regulatory mechanism to avoid photodamage of photosynthetic apparatus (Demming-Adams et al. 1996). The qp represent the fraction of open PSII reaction centres (Genty et al. 1989) and can contribute to protect the photosynthetic apparatus by transferring electrons to $\mathrm{O}_{2}$ under drought stress (Ort and Baker 2002). There was a strong positive correlaltion identified between $\Phi_{\mathrm{PSII}}$ and $\mathrm{q}_{\mathrm{P}}(r=0.93$, $P<0.001)$. This finding may indicate that a $\mathrm{q}_{\mathrm{p}}$ is associated with a deactivation of PSII excitation.

A very common response to drought is an increased production of compatible organic solutes, such as soluble sugars, sugar alcohols, proline, and betaines (Serraj and Sinclair 2002). Proline and carbohydrates are the two most important organic solutes that are accumulated in higher plants under drought conditions (Changhai et al. 2010). The current data show increased leaf concentrations of sucrose which seems to play a key role in the integration of plant growth and appear to be part of a wider mechanism for balancing carbon acquisition and allocation within and between organs (Farrar et al. 2000). During drought stress the decrease of carbon assimilation caused by low photosynthetic rates may contribute to increasing carbohydrate concentrations in leaves (Arndt et al. 2001). Furthermore, proline concentration markedely increased in leaves of stressed plant compared to well irrigated as water deficit intensified. According to Clifford et al. (1998), leaf proline accumulation seems to be a necessary and important mechanism to regulate redox potentials and functions as a hydroxyl radical scavenger. In response to osmotic stress induced by PEG-6000, Z. lotus seedlings increase the organic solute accumulation, such as proline and soluble sugars, in leaves and the activity of antioxidant enzymes, such as catalase and ascorbate peroxidase, in roots 
(Maraghni et al. 2014). It was found (Gorai et al. 2015) that proline accumulation was significantly correlated to low $\psi_{\mathrm{w}}$ suggesting the involvement of this solute in osmotic adjustment. Similar trends of increase in proline and carbohydrates in leaves of some Ziziphus species during drought stress were also reported (Choudhary et al. 1996, Clifford et al. 1998, Arndt et al. 2001, Maraghni et al. 2011, 2014).

Overall, results of this study provide insight of the different mechanisms developed by Z. lotus in order to deal with water shortage. This xerophytic shrub was able to overcome drought stress by reducing its photosynthetic performance and water relations, and finally modifying its leaf anatomical tissues. Consequently, an osmotic adjustment was developed by this shrub as a tolerance mechanism to withstand drought stress.

\section{References}

Arndt S.K., Clifford, S.C., Wanek, W. et al:: Physiological and morphological adaptations of the fruit tree Ziziphus rotundifolia in response to progressive drought stress. - Tree Physiol. 21: 705-715, 2001.

Aroca R., Porcel R., Ruiz-Lozano J.M.: Regulation of root water uptake under abiotic stress conditions. - J. Exp. Bot. 63: 4357, 2012.

Augé M.R., Stodola A.J.W., Moore J.L. et al:: Comparative dehydration tolerance of foliage of several ornamental crops. - Sci. Hortic.-Amsterdam 98: 511-516, 2003.

Bacelar E.A., Correia C.M., Moutinho-Pereira J.M. et al.: Sclerophylly and leaf anatomical traits of five field-grown olive cultivars growing under drought conditions. - Tree Physiol. 24: 233-239, 2004.

Baker N.R., Rosenqvist E.: Applications of chlorophyll fluorescence can improve crop production strategies: an examination of future possibilities. - J. Exp. Bot. 55: 1607-1621, 2004.

Bates L.S., Waldren R.P., Teare I.K.: Rapid determination of free proline for water stress studies. - Plant Soil 39: 205-208, 1973.

Bosabalidis A.M., Kofidis G.: Comparative effects of drought stress on leaf anatomy of two olive cultivars. - Plant Sci. 163: 375-379, 2002.

Boussadia O., Ben Mariem F., Mechri B. et al.: Response to drought of two olive tree cultivars (cv Koroneki and Meski). - Sci. Hortic.-Amsterdam 116: 388-393, 2008.

Callister A.N., Arndt S.K., Adams M.A.: Comparison of four methods for measuring osmotic potential of tree leaves. Physiol. Plantarum 127: 383-392, 2006.

Ceccarelli S., Grando S. Maatougui M. et al.: Plant breeding and climate changes. - J. Agri. Sci. 148: 627-638, 2010.

Changhai S., Baodi D., Qiao Y.Z.: Physiological regulation of high transpiration efficiency in winter wheat under drought conditions. - Plant. Soil. Eviron. 56: 340-347, 2010.

Chapotin S.M., Razanameharizaka J.H., Holbrook N.M.: Baobab trees (Adan-sonia) in Madagascar use stored water to flush new leaves but not to support stomatal opening before the rainy season. - New. Phytol. 169: 549-559, 2006.

Chaves M.M.: Effects of water deficits on carbon assimilation. J. Exp. Bot. 42: 1-16, 1991.

Choudhary R., Sankhla N., Trivedi S. et al.: Photosynthesis, chlorophyll fluorescence, osmoregulatory solutes and enzyme activities in ber (Ziziphus rotundifolia) under moisture stress. - Proc. Plant. Growth Regul. Soc. Am. 23: 206-210, 1996.

Clifford S.C., Arndt S.K., Corlett J.E. et al.: The role of solute accumulation, osmotic adjustment and changes in cell wall elasticity in drought tolerance in cell wall elasticity in drought tolerance in Ziziphus mauritiana (Lamk.). - J. Exp. Bot. 49: 967-977, 1998.

Demming-Adams B., Adams III W.W., Barker D.H. et al.: Using Chlorophyll fluorescence to assess the fraction of absorbed light allocated to thermal dissipation of excess excitation. Physiol. Plantarum 98: 253-264, 1996.

De Smedt S., Cuní Sanchez A., Van den Bilcke N. et al.: Functional responses of baobab (Adansonia digitata L.) seedlings to drought conditions: differences between western and south-eastern Africa. - Environ. Exp. Bot. 75: 181-187, 2012.

Farrar J., Pollock C., Gallanger J.: Sucrose and the interaction of metabolism in vascular plants. - Plant Sci. 154: 1-11, 2000.

Flexas J., Escalona J.M., Medrano H.: Water stress induces different photosynthesis and electron transport rate regulation in grapevine. - Plant Cell Environ. 22: 39-48, 1999.

Genty B., Briantais J.M., Baker N.R.: The relationship between the quantum yield of photosynthesic electron transport and quenching of chlorophyll fluorescence. - Biochim. Biophys. Acta 990: 87-92, 1989.

Gorai M., Maraghni M., Neffati M.: The relationship between phenological traits and water potential patterns of the wild jujube Ziziphus lotus in southern Tunisia. - Plant Ecol. Divers. 3: 273-280, 2010.

Gorai M., Laajili W., Santiago L.S. et al.: Rapid recovery of photosynthesis and water relations following soildrying and re-watering is related to the adaptation of desert shrub Ephedra alata subsp. alenda (Ephedraceae) to arid environments. Environ. Exp. Bot. 109: 113-121, 2015.

Gorantla M., Babu P.R., Lachagari V.B.R. et al.: Identification of stress-responsive genes in an indica rice (Oryza sativa L.) using ESTs generated from drought-stressed seedlings. - J. Exp. Bot. 58: 253-265, 2007.

Kala S., Godara A.K., Sehrawat S.K. et al.: Effect of moisture stress on leaf water potential, osmotic potential and relative water content in Ziziphus species. - Haryana J. Hort. Sci. 36 210-211, 2007.

Kawaguchi R., Girke T., Bray E.A. et al.: Differential mRNA trans-lation contributes to gene regulation under non-stress and dehydration stress conditions in Arabidopsis thaliana. Plant J. 38: 823-839, 2004.

Kreuzwieser J., Rennenberg H.: Molecular and physiological responses of trees to waterlogging stress. - Plant Cell Environ. 37: 2245-2259, 2014.

Kulkarni M., Schneider B., Raveh E. et al.: Leaf anatomical characteristics and physiological responses to short term drought in Ziziphus mauritiana (Lamk.). - Sci. Hortic.Amsterdam 124: 316-322, 2010.

Lawlor D.W., Cornic G.: Photosynthetic carbon assimilation and associated metabolism in relation to water deficits in higher plants. - Plant Cell Environ. 25: 275-294, 2002.

Le Floc'h E.: [Contribution to an ethnobotanical study of Tunisian flora]. Pp. 402. Publications Scientifiques Tunisiennes, Tunis 1983. [In French]

Maraghni M., Gorai M., Neffati M.: Seed germination at different temperatures and water stress levels, and seedling emergence from different depths of Ziziphus lotus. - S. Afr. J. Bot. 76: 453-459, 2010.

Maraghni M., Gorai M., Neffati M.: The influence of waterdeficit stress on growth, water relations and solute accumulation in wild jujube (Ziziphus lotus). - J. Ornam. Hortic. Plant. 1: 6372, 2011.

Maraghni M., Gorai M., Neffati M. et al.: Differential responses to drought stress in leaves and roots of wild jujube, Ziziphus 
lotus. - Acta Physiol. Plant. 36: 945-953, 2014.

Maxwell K., Johnson G.N.: Chlorophyll fluorescence - a practical guide. - J. Exp. Bot. 51: 659-668, 2000.

McDowell N., Pockman W.T., Allen C. et al.: Mechanisms of plant sur-vival and mortality during drought: why do some plants survive while otherssuccumb to drought? - New Phytol. 178: 719-739, 2008.

Morgan J.M.: Osmoregulation and water stress in higher plants. - Annu. Rev. Plant Physio. 35: 299-319, 1984.

Müller P., Li X.P., Niyogi K.K.: Non-photochemical quenching. a response to excess light energy. - Plant Physiol. 125: 15581566, 2001.

Nikinmaa E., Hölttä T., Hari P. et al.: Assimilate transport in phloem sets conditions for leaf gas exchange. - Plant Cell Environ. 36: 655-669, 2013.

Ort D.R., Baker N.R.: A photoprotective role for $\mathrm{O}_{2}$ as an alternative electron sink in photosynthesis? - Curr. Opin. Plant Biol. 5: 193-198, 2002.

Perera I.Y., Hung C.Y., Moore C.D. et al.: Trans-genic Arabidopsis plants expressing the type 1 inositol 5-phosphatase exhibit increased drought tolerance and altered abscisic acid signaling. - Plant Cell 20: 2876-2893, 2008.

Raven J.A.: Selection pressures on stomatal evolution. - New Phytol. 153: 371-386.

Reddy A.R., Chaitanya K.V., Vivekanandan M.: Drought induced responses of photosynthesis and antioxidant metabolism in higher plants. - J. Plant Physiol. 161: 1189-1202, 2004.

Rouhi V., Samson R., Lemeur R. et al.: Photosynthetic gas exchange characteristics in three different almond species during drought stress and subsequent recovery. - Environ.
Exp. Bot. 59: 117-129, 2007.

Serraj R., Sinclair T.R.: Osmolyte accumulation: can it really help increase crop yield under drought conditions? - Plant Cell Environ. 25: 333-341, 2002.

Sharkey T.D.: Water stress effects on photosynthesis. Photosynthetica 24: 651-658, 1990.

Song J., Shi G.W., Xing S. et al.: Ecophysiological responses of the euhalophyte Suaeda salsa to the interactive effects of salinity and nitrate availability. - Aquat. Bot. 91: 311-317, 2009.

Souza R.P., Machado E.C., Silva J.A.B. et al.: Photosynthetic gas exchange, chlorophyll fluorescence and some associated metabolic changes in cowpea (Vigna unguiculata) during water stress and recovery. - Environ. Exp. Bot. 51: 45-56, 2004.

Tardieu F., Simmonneau T.: Variability among species of stomatal control under fluctuating soil water status and evaporative demand: modeling isohydric and anisohydric behaviours. - J. Exp. Bot. 49: 419-432, 1998.

Torrecillas A., Galego R., Pérez-Pastor A. et al: Gas exchange and water relations of young apricot plants under drought conditions. - J. Agri. Sci. 132: 445-452, 1999.

van Kooten O., Snel J.F.H.: The use of chlorophyll fluorescence nomenclature in plant stress physiology. - Photosynth. Res. 25: 147-150, 1990.

Zhang S.R., Song J., Wang H. et al.: Effect of salinity on seed germination, ion content and photosynthesis of cotyledons in halophytes or xerophyte growing in Central Asia. - J. Plant Ecol. 3: 259-267, 2010.

(C) The authors. This is an open access article distributed under the terms of the Creative Commons BY-NC-ND Licence. 